\title{
Digital Parenting Services: University Integrated With Society
}

\author{
Kartika Rinakit Adhe ${ }^{1, *}$ Wagino² Muchamad Arif Al Ardha ${ }^{3}$ Muhammad Syahidul
}

\author{
$\mathrm{Haq}^{4}$ \\ ${ }^{1}$ Department of Early Childhood Education, Faculty of Education, State University of Surabaya, Surabaya, Indonesia \\ ${ }^{2}$ Department of Special Education, Faculty of Education, State University of Surabaya, Surabaya, Indonesia \\ ${ }^{3}$ Department of Physical Education, Faculty of Sport Science, State University of Surabaya, Surabaya, Indonesia \\ ${ }^{4}$ Department of Management Education, Faculty of Education, State University of Surabaya, Surabaya, Indonesia \\ *Corresponding author.Email: kartikaadhe@unesa.ac.id
}

\begin{abstract}
This research aims to make advancement in the area of parenting by building a digital service. This service integrates parenting information in the surrounding society. Services in the form of websites that can be opened by the public and contain information. The method used in this research are research and development with ADDIE type. The samples consist of 50 participants. Trials are conducted with small trials as well as large trials onwards. The results of this study are carried out starting from the assessment of products and materials and then testing the service that was done. The feasibility assessment by material experts obtained a score of $93.18 \%$ with both criteria and categories worthy. Eligibility assessment by media experts obtained a score of $93.75 \%$ with good criteria and feasible categories. Assessment of the feasibility of small group trials received a total score of $53.61 \%$ and large group trials received a total score of $68.56 \%$. The implication of this research shows that digital parenting services help the public understand the parenting that will be applied to children.
\end{abstract}

Keywords: Component, parenting, digital services

\section{INTRODUCTION}

Formal which was pioneered respectively by Clarke and Emerson [1]. Nowadays, Indonesia is undergoing a change from the manual era to the digital era. This change is a demand of technological progress. Technology is a facility offered for human convenience (Omotosho, Lateef, Amusa, $\&$ Bello, 2015). The convenience provided supports daily behavior, not using manual tools but modern tool (Yousaf, et al., 2019). How to obtain information is also facilitated by technology? When you need to read, humans do not need to buy books, but can through the internet. Open insight easily uses digital service access (Barak, 2018).

This trend is an advantage of the digital era. Anywhere at any time humans can get information easily. But on the other hand, the accuracy of the information contained in digital accesses is a problem (Liang \& Feng, 2018). Therefore, the society needs the integration of information provided by university academics to the society.

Digital information facilities that can be provided by university academics about problems that emerge in society are considered as a polemic of parenting. Parenting becomes important (Kirby \& Hodges, 2018) since improper parenting system leads a bad character formation of generation.

The problem that arises in Indonesia is about marriage at a young age which is increasing every year (Berliana, et al.,
2018). Deputy for Family Planning and Reproductive Health, Listyawardani said "the number of Indonesian underage marriages is still quite high, the marriage rates for underage Indonesian children touched more than 20 percent". Factors of young marriage include cultural factors, traditional factors, religious factors, poverty factors and promiscuity factors (Berliana et al., 2018).

First, the cultural factor is the most Indonesian people believe for generations that early-age married is better because it would be easy to have children. Second, the traditional factor encourages them to do the early-age married due to their parents or ancestors who did the same thing. Third, the religious factor which makes society believes that married is a part of worship and this is done to avoid free sex. Then, the poverty factor encourages the indigents to get married as a solution to get better life. Lastly, promiscuity causes married by accident.

The problem of early-age married is the young couple has limited knowledge of parenting. It forms disordered children characters. There is no data distribution on married young couple data distribution. Thus, the easy way to provide them of knowledge and information is digital access through website. Digital parenting services are available on the website of the Faculty of Education, Universitas Negeri Surabaya (UNESA). Parenting is a system for parents about how to treat a child by educating, guiding, disciplining and protecting children in reaching the process of maturity, how to establish expected norms by 
society in general and how to educate children as a conscious and planned efforts to provide stimulation for children.

Guiding is intended when a child is given repeated treatment with a mentoring stimulation. -Yet, if the child is unsuccessful, then the parent -should - accompany a child continually. Moreover, disciplining children is important, since children need to know how to behave which is acceptable in society.

There are three types of parenting. First, authoritarian parenting is - strict rules from parents and child freedom is severely restricted (Yadav \& Chandola, 2019). If the parents impose their will on the child, then this parenting is indirectly applied. On digital service, it is important to convey the weaknesses and authoritarian advantages, so that parents can review and determine the sustainability of digital service use.

Second, democratic is - an open attitude between parents and children (Lo Cricchio, Lo Coco, Cheah, \& Liga, 2019). Then, permissive is an unlimited freedom for children to behave according to their own desires (Kirby \& Hodges, 2018). Important issues related to parenting would - be accessed easily via the internet. The reason is the data needs could be accessed anywhere and anytime, for example through the website.

Website is one of information media on the internet. It is a collection of website pages, which is usually summarized in a domain or subdomain, located on the World Wide Web (www) on the Internet. A web page is a document written in HTML (Hyper Text Markup Language) format, which is almost always accessible via HTTP, a protocol that conveys information from a website server to be displayed to users through a web browser (Ramos, Rita, \& Moro, 2019). All publications from these websites are able to form a very large information network.

The pages of the website would be accessible via URL which is commonly called the Homepage. This URL organizes the pages of the site to become a hierarchy, though, the hyperlinks on the page organize the readers and tell them the overall order and how this information flows. Some websites require subscriptions (input data) so that users can access some or all of the contents of the website (Manzoor, Hussain, Sohaib, Hussain, \& Alkhalaf, 2019).

The results of this study aim to create renewal in the field of digital information, the benefits of this study are to facilitate parents at a young age in determining appropriate parenting for their children. This service is also made interesting by viewing videos containing parenting information. There is also an online interactive service to consult with parenting experts. Parenting experts come from lecturers in the early childhood education department.

\section{RESEARCH METHOD}

This research used the research and development method by developing the academic services information system model at the Faculty of Education, State University of Surabaya. Media development in accordance with the stages of the ADDIE (Analyze - Design - Development -
Implementation - Evaluation) developmentally model (Gooch, 2012).

Trial subjects in this development include validation and lecturer trials. Each research activity certainly has parties who have a role in each research activity. -They are material experts, media experts, and users (Desai, 2006). Users in this population of this study are all individuals who experience parenting problems in Surabaya. They were 87 participants whereas 50 participants were taken randomly as samples. They fulfilled the requirements as those who lack knowledge of parenting, did the early-age married, and married by accident.

Data collection techniques in this study used questionnaire. It was chosen to obtain data compatibly. It was distributed through google form. It was filled out by students, lecturers, and parents. The aspects assessed in the questionnaire are ease of access, speed of access, flexibility, completeness, relevance, presentation of information, effective and efficient (Walliman, 2017).

\section{RESEARCH RESULT AND DEVELOPMENT}

The result of development research is a product that is scientifically studied. At each stage it has been based on product development design.

\subsection{Analyze}

The initial stage conducted by researchers in making digital parenting is to observe the needs of issues related to parenting (Calzada, Sales, \& O'Gara, 2019). First, identify existing problems, then do a needs analysis and explore the existing potential of the issue. Afterwards, collect various data and information that are used as material to strengthen and to develop certain products in order to overcome the problem. Analysis is carried out from parenting theory and current issues related to parenting.

\subsection{Design}

At this stage, there are several steps that must be done including the following:

1) For whom digital parenting is designed

Digital parenting is designed for digital needs regarding basic concepts of parenting and parenting issues so parents can determine parenting for their children.

2) What abilities will be achieved

First, digital parenting aims to help in the parenting socialization activities. Second, digital parenting aims to increase effectiveness in responding to parenting issues. Third, this data aims to be accessible to all parents who need information 


\subsection{Development}

At this stage the development has begun to develop digital parenting based on flowcharts and storyboards that have been made at the design stage. There are steps at this stage First, make story board, before carrying out data production, it requires several designs in the form of storyboards.

This page has a function to choose the parenting theme that was created. This view is intended to help users in accessing the display easily.

This page displays show the entire collection owned by the service. On this page, we can find out the characteristics of parenting. It assists parents to know what parenting has been implemented.

This page displays show the entire collection owned by the service. It consists of important parenting issues. For example, breastfeeding for children.

Second stage is production. The development of production phase is done by making the main page design in accordance with the theme of parenting with xampp through coding activitie. The researcher makes a product design that will be used in developing another design carried out by researchers

Third stage is validation process. Media validation is the process of evaluating digital parenting. The purpose is to provide an assessment of digital parenting so that the weaknesses and strengths of the product can be identified. The quality and suitability of a media can be used in learning that is determined based on the results of expert assessments.

This validation is done by involving experts who had experienced about media development. They are divided into two namely material experts and media experts who have different tasks. The task of material experts is to validate the content of material from digital parenting.

\subsection{Product Testing}

After doing digital parenting web production and revision in accordance with experts' advice product trials are done to determine the feasibility and effectiveness of the web parenting. They are divided into 2 activities: (1) A small group trial consisting of 15 users; (2) A large group trial consisting of 50 users.

1) Trial of Small Groups in Functional Suitability aspects. It is made up of FIP members.

2) Large Group Trial of Functional Suitability aspect. It consists of parents who related to research.

\subsection{Implementation}

The next stage is the stage of implementing digital parenting web products at FIP Unesa. This implementation phase aims to obtain the value data. Previously the questions used in conducting the test would be validated -. Next is conducting a test or field test on the respondent. Then, calculating Validity and Reliability of Problems. The validity of the questions is done to determine which questions are valid and which are not valid. The Validity Test is used to find out the validity of each question, so that it can be known significant or not. The feasibility assessment by the material experts obtained a score of 93.18\% with appropriate criteria and categories. The feasibility assessment by media experts obtained a score of 93.75\% with good criteria and feasible categories. Assessment of the feasibility showed that the total score of small group trials is of $53.61 \%$ and for large group trials is $68.56 \%$. According to the data, parents with lack of parenting knowledge, who did early-age married, and who had married by accident require communicative education facilities and obtain information compatibly.

Data and information needed lead to important issues such as what the pattern of care is. People who do not comprehend of parenting then they do not have a basic knowledge about how to take care of children properly. Moreover, parents who did early-age married use the oldfashioned parenting style would not realize what parenting is being applied. Parents who are married by accident have no readiness in how to take care of children, so if one is improper it impacts to bad consequences (Coe, Davies, Hentges, \& Sturge-Apple, 2020; Toscano, Soares, \& Mesman, 2020). Based on the explanations, knowledge of parenting is needed in daily life to look after the children, and to educate children as expected (Kirby \& Hodges, 2018).

\subsection{Evaluation Phase}

At this stage, an evaluation is occurred for each stage, for instance at the development stage, an evaluation is carried out each time of activities. It is done to improve the digital parenting automation system that has been validated and others. So, every stage in the ADDIE model always involves an evaluation phase for improvements that will ultimately make a product better and valuable. Furthermore, an evaluation of media development is needed and it is followed by an interactive session to facilitate the users who have questions. In addition, it also requires experts who are able to be invited to the interactive dialogue.

\section{CONCLUSION}

This paper demonstrates how parenting program can be adopted using a digital platform. It indicates the need to expand parenting program so that more parents can benefits from it

\section{ACKNOWLEDGMENT}

The success of this research has been completed due to the support of the faculty of education in Unesa. In addition, support research was successfully obtained from expert lecturers, 
participants who were pro-active in product development.

\section{REFERENCES}

Barak, M. (2018). Are digital natives open to change? Examining flexible thinking and resistance to change. Computer \& Education, 121, 115-123.

Berliana, S. M., Kristinadewi, P. A. N., Rachmawati, P. D., Fauziningtyas, R., Efendi, F., \& Bushy, A. (2018). Determinants of early marriage among female adolescent in Indonesia. International Journal of Adolescent Medicine and Health, O(0), 1-6, https://doi.org/10.1515/ijamh-2018-0054

Calzada, E. J., Sales, A., \& O’Gara, J. L. (2019). Maternal depression and acculturative stress impacts on Mexican-origin children through authoritarian parenting. Journal of Applied Developmental Psychology, 63, 65-75.

Coe, J. L., Davies, P. T., Hentges, R. F., \& SturgeApple, M. L. (2020). Understanding the nature of associations between family instability, unsupportive parenting, and children's externalizing symptoms. Development and Psychopathology, 32(1), 257-269

Desai, V. P. R. (2006). Doing development research. London: Sage Publications

Gooch, D. L. (2012). Research, development, and validation of a school leader's resource guide for the facilitation of social media use by school staff (Doctoral dissertation, Kansas State University).

Kirby, G., \& Hodges, J. (2018). Parenting of preschool and school-aged children. In Handbook of parenting and child development across the lifespan. Cham: Springer International Publishing, 609-629.

Liang, C. Y. Ip. C., \& Feng, J. Y. Determinants of public attitude towards a social enterprise crisis in the digital era: Lessons learnt from THINX. Public Relation Review, 44(5), 784-793.

Lo Cricchio, M. G., Lo Coco, A., Cheah, C. S. L., \& Liga, F. (2019). The good parent: Southern Italian mothers' conceptualization of good parenting and parent-child relationships. Journal Family Issues, 40(12), 1583-1603.

Manzoor, M., Hussain, W., Sohaib, O., Hussain, F. K., \& Alkhalaf, S. (2019). Methodological investigation for enhancing the usability of university websites. Journal of Ambient Intelligence and Humanized Computing, 10(2), 531-549.

Omotosho, A. O., Lateef, E. B., Amusa, O. I., \& Bello, T. O. (2015). Information and communication technology adoption and use among students of a Nigerian University for distance learning. Library Philosophy and Practice, O(1), 1-19.

Ramos, R. F., Rita, P., \& Moro, S. (2019). From institutional websites to social media and mobile applications: A usability perspective. European Research on Management and Business Economics, 25(3), 138-143.

Toscano, C., Soares, I., \& Mesman, J. (2020). Controlling parenting behaviors in parents of children born preterm: A meta-analysis. Journal of Developmental \& Behavioral Pediatrics, 41(3), 230241.

Walliman, N. (2017). Research methods: The basics. London: Routledge.

Yadav, P. P. S., \& Chandola, R. (2019). Authoritarian parenting style and its effect on self-esteem and coping strategies of 21 year old girl. Global Journal Research Analyze, 8(3), 100-101.

Yousaf, K., Mehmood, Z., Saba, T., Rehman, A., Munshi, A. M., Alharbey, R., \& Rashid, M. (2019). Mobile-health applications for the efficient delivery of health care facility to People with Dementia (PwD) and support to their carers: A survey. BioMed Research International, 1-27, https://doi.org/10.1155/2019/7151475. 